DOI: https://doi.org/10.31073/mivg20180108-143।

Available at: http://mivg.iwpim.com.ua/index.php/mivg/article/view/143

УДК 631.67;626.86

\title{
РИЗИКИ ПІДТОПЛЕННЯ ТА ШЛЯХИ ЇХ ЗМЕНШЕННЯ В ЗОНІ ЗРОШЕННЯ ПІВНІЧНО-КРИМСЬКОГО КАНА.ЛУ
}

О.І. Харламов *

Інститут водних проблем і меліорації НААН. Київ, Україна;

littps://orcid.org/0000-0002-9019-3445; e-mail: 1harlam911@gmail.com

Анотація. Встановлено інтенсивність ризиків підтопления та закономірності режиму РГВ у багаторічному розрізі в зоні Північно-Кримського каналу в безстічних умовах на фоні вертикального дренажсу. Розроблено конструкиію дренажної системи зі спільною дісю горизонтального та вертикального дренажу.

Ключові слова: зрошення, підтоплення, дренаж, рівні грунтових вод, безстічний рельеф місцевості.

Постановка питання. $\mathrm{y}$ південному регіоні України багаторічне зрошення земель на слабодренованих територіях зумовлює інтенсивний підйом рівня грунтових вод (РГВ), розвиток процесів підтоплення, засолення грунтів і грунтових вод на зрошуваних масивах та прилеглих територіях, що своєю чергою викликало необхідність будівництва систем інженерного дренажу та моніторингу гідрогеолого-меліоративної ситуації [1, 9]. Особливо інтенсивно ці процеси відбуваються в умовах рівнинного слабостічного та безстічного рельєфу місцевості [7]. Один 3 таких масивів розташований на території Херсонської області в зоні зрошення Північно-Кримського каналу (ПКК). Тривала експлуатація зрошувальних та дренажних систем на масиві призвела до того що в межах замкнених знижень процеси затоплення i підтоплення продовжують періодично проявлятися, особливо у періоди інтенсивних опадів та поливів.

Метою роботи є: встановлення закономірностей розвитку процесів затоплення і підтоплення в зоні зрошення на безстічних територіях, оцінка стану гідрогеолого-меліоративної ситуації, визначення ефективності роботи вертикального дренажу та розроблення удосконалених конструкцій дренажних систем.

Методика досліджень. Дослідження проведено на дослідно-виробничій ділянці (ДВД) площею 8500 га, яка розташована у селі Подо-Калинівка Олешківського району Херсонської області і належить до типової у зоні зрошення ПКК і Краснознам'янської зрошувальної системи (рис. 1). Оцінку ризиків

\footnotetext{
* під керівництвом канд. техн. наук, с.н.с. Д.П. Савчука
} (C) O.I. Харламов, 2018

2018 • № 2 МЕЛІОРАІШЯ І ВОДНЕ ГОСПОДАРСТВО підтоплення, його просторове поширення та ефективність роботи дренажних систем визначали за результатами аналізу режимних спостережень Каховської гідрогеолого-меліоративної партії та експлуатаційних даних. На ділянці відібрано контрольні спостережні свердловини 3 тривалим терміном спостереження. Опрацювання даних полягало в побудові графіків та карт глибин залягання РГВ у різні за водністю роки, порівнянні фактичних і критичних глибин залягання РГВ.

Характеристика району дослідження. Район досліджень розташований на великій безстічній території загальною площею близько 70 тис. га. Ширина ділянки становить 10-15 км, довжина - понад 50 км. Територія прилягає до каналу і широкою смугою простягається від Каховського водосховища через населені пункти Нова Маячка, Стара Маячка, Подо-Калинівка, Тарасівка, Абрикосівка, Великі Копані.

Район розташований в межах старовинної другої (середньої) супіщано-лесової надзаплавної тераси дельти Дніпра i характеризується складними природними та водогосподарськими умовами. Клімат району континентальний 3 малосніжною зимою i жарким літом, частими посухами i суховіями. Середня багаторічна кількість атмосферних опадів становить 480 мм/рік, у посушливі роки - 250-270 мм/рік, а у вологі 500-700 мм/рік. Добовий максимум опадів, який був зафіксований 21 липня 1956 року, становить 189 мм. У районі один раз на 5-10 років ймовірні сильні дощі 3 кількістю опадів 50 мм і більше, а інтенсивність опадів досягає 0,19-0,55 мм/хв [6]. 


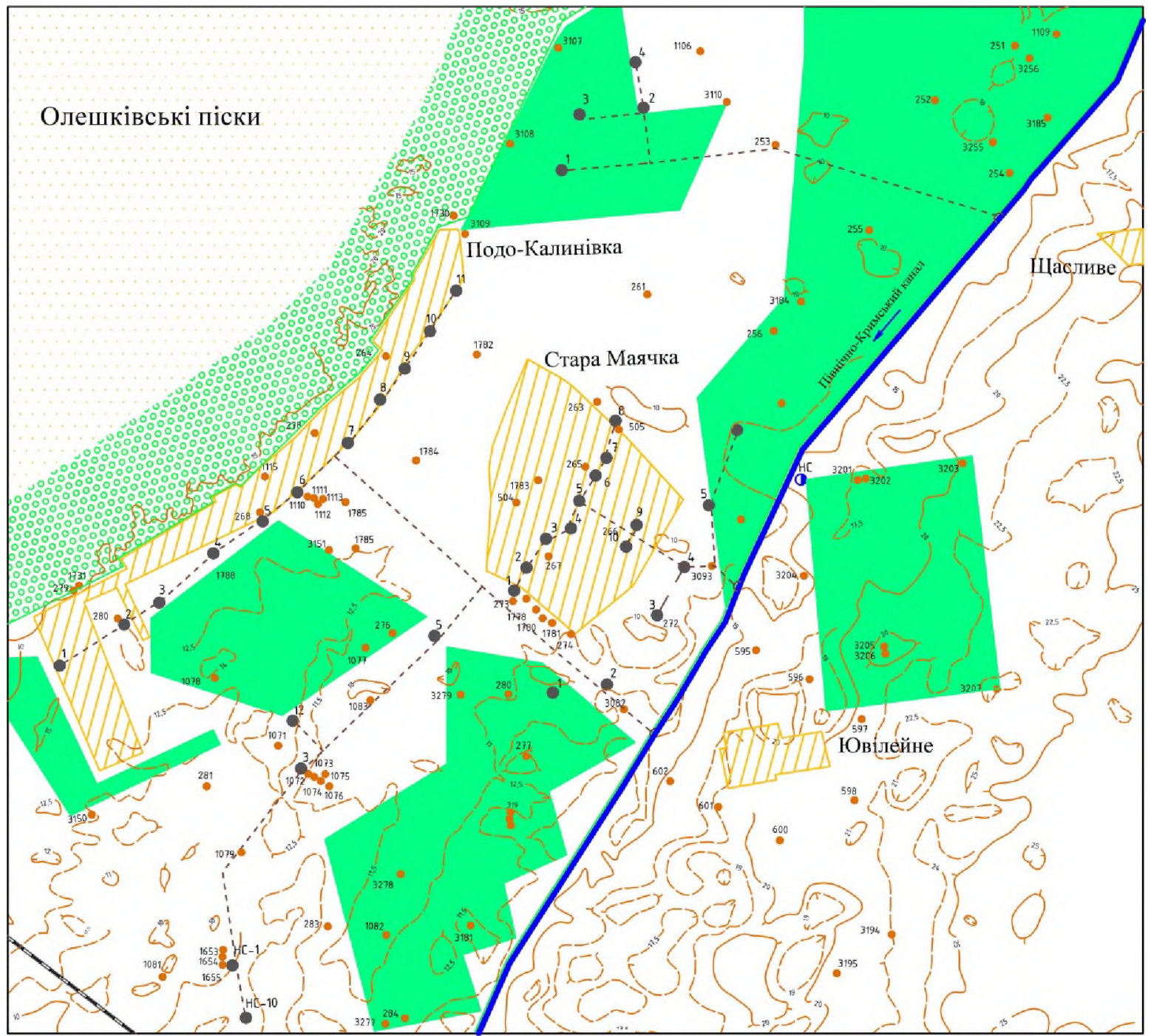

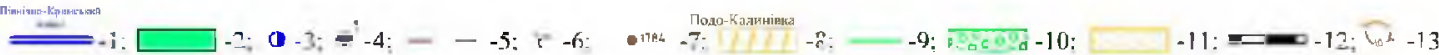

Рис. 1. Схема дослідно-виробничої ділянки

1 - Північно-Кримський канал (27-43 км); 2 - зрошувальні системи; 3 - насосна станція 4 - свердловини вертикального дренажу та їх номери; 5 - напірний трубопровід;

6 - дренажне гирло; 7 - спостережні свердловини та їх номери; 8 - населений пункт; 9 - лісосмуга; 10 - лісовий масив; 11 - пустеля; 12 - залізна дорога; 13 - горизонталі місцевості

Рельєф місцевості рівнинний 3 великою кількістю безстічних знижень. Абсолютні відмітки на терасі становлять близько 8-10 м, а на вододілах - 25-40 м. Геологічна будова на масиві представлена шарами суглинистих грунтів, піску та вапняку 3 коефіцієнтами фільтрації 0,2-0,6, 10-25 та 50-250 м/добу відповідно. У шарі піску зустрічаються лінзи суглинків товщиною до 5 м. Загальна водопровідність водоносної товщі становить понад $3000 \mathrm{M}^{2} /$ добу [1,3].

Система захисту території від підтоплення представлена свердловинами верти- кального дренажу, які введено в експлуатацію у 1972 р. Свердловини розташовані за лінійною схемою. Відстань між ними становить 500-1000 м, глибина закладання близько 65 м. Засоби відкачування представлені насосами типу ЕЦВ, які знаходяться на глибинах 15-21 м. Забір підземних вод здійснюється переважно із вапнякового водоносного горизонту. Дренажний стік відводиться у ПКК за допомогою напірних трубопроводів діаметром 1000 мм. Мінералізація дренажної води становить менше 1 г/дм³ $7-12{ }^{\circ} \mathrm{C}$, вода придатна для зрошення. 
Результати досліджень. Тривале функціонування зрошувальних систем та інтенсивні поливи присадибних ділянок у населених пунктах зумовили регіональний підйом РГВ, формування осередків підтоплення на понижених ділянках місцевості та періодичні ускладнення гідрогеолого-меліоративної ситуації. Підйоми РГВ вище критичних глибин та затоплення територій спостерігались у вологих 1980-1981 роках, після багатосніжної зими 1984-1985, у дощові періоди червня 1986, 1989, 2010, 2015 рр., січня 1998, липня 2018 р. (рис. 2). Найбільші ускладнення водно-екологічної ситуації виникали в періоди надзвичайних підтоплень 1998, 2010 та 2015 р [2,10].

Істотно впливала на гідрогеологомеліоративну ситуацію на ділянці робота вертикального дренажу. Виділяються два періоди його функціонування: 1977-1995рp. - стабільної та 1996-2018 pp. - недостатньої роботи. У період стабільної роботи на території с. ПодоКалинівка РГВ залягали нижче критичних глибин ( 2 м). У центральній частині зниження в окремі надмірно вологі періоди грунтові води підіймались близько до критичних показників (спостережна свердловина 1110). На схилах зниження грунтові води залягали на глибинах 4-5,5 м (спостережні свердловини $264,279)$. Загалом на ділянці чітко простежується тенденція до підйому рівня.

У період недостатньої роботи дренажу спостерігалось залягання РГВ вище критичних глибин i формування стійкої зони підтоплення в межах днищ знижень. У періоди 3 аномальними опадами в цій зоні виникали надзвичайні затоплення i підтоплення. На схилах знижень грунтові води знаходились на глибинах 3-4 м і мають стійку тенденцію підйому РГВ. У межах знижень щорічна інтенсивність підйому РГВ становить близько 4 см, на схилах знижень - 2-3 см. У сучасних умовах виникла несприятлива ситуація, істотно зменшилась зона аерації та іiі буферна здатність, через що у період інтенсивних опадів збільшується загроза виникнення масштабних підтоплень. Потужності існуючого дренажу не забезпечували належного захисту території.

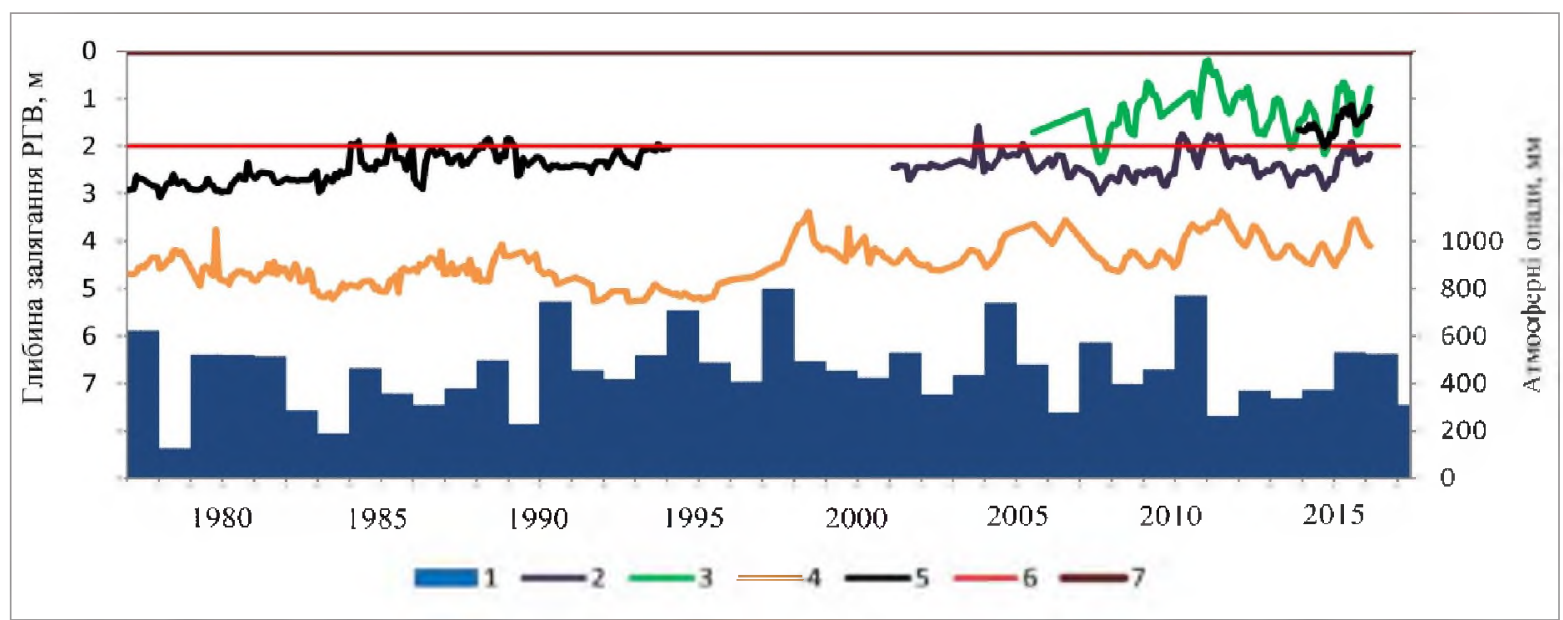

Рис. 2. Динаміка глибин залягання рівня грунтових вод у районі с. Подо-Калинівка (за даними Каховської ГГМП):

1 - річна кількість атмосферних опадів; 2-5 - спостережні свердловини ( 2 - № 264; 3 - №268; 4 - № 279; 5 - № 1110); 6 - критична глибина залягання РГВ; 7 - поверхня землі

Аналіз поширення площ РГВ показав, що на початковому періоді експлуатаціі дренажу (1973р.) підтоплення охоплювало близько $30 \%$ площ, у період стабільної роботи (1980 р.) - близько $0,15 \%$, після тривалого терміну експлуатації та недостатньої роботи дренажу $(2014,2018$ рр.) - до 7\%, 30\% відповідно (таблиця).

Зменшення обсягу моніторингу у 1990-х роках призвело до втрати можливості своєчасного виявлення розвитку процесів підто- плення, прогнозування їх наслідків та оперативного вжиття необхідних заходів.

Узагальнення результатів дослідження та досвіду боротьби $з$ процесами затоплення та підтоплення показало, що головними причинами підтоплення у районі досліджень є комплекс факторів, який включає надмірні атмосферні опади, скупчення поверхневого стоку в низинах, підпір грунтових вод з боку основного водоносного горизонту, фільтрація води 3 водосховища і каналів, інфільтрація на зрошуваних 
1. Площі територій з різними РГВ у с. Подо-Калинівка та на прилеглих землях, га

\begin{tabular}{|c|c|c|c|c|c|}
\hline $\begin{array}{c}\text { Глибина } \\
\text { залягання } \\
\text { РГВ, м }\end{array}$ & 1973 & 1980 & 1998 & 2014 & 2018 \\
\hline & 416 & 0 & 313 & 193 & 403 \\
\hline $1-2$ & 2067 & 13 & 3472 & 376 & 2134 \\
\hline $2-3$ & 3338 & 215 & 793 & 3307 & 1589 \\
\hline $3-5$ & 635 & 5959 & 1136 & 2945 & 2077 \\
\hline$>5$ & 2044 & 2313 & 2786 & 1679 & 2297 \\
\hline Всього & 8500 & 8500 & 8500 & 8500 & 8500 \\
\hline
\end{tabular}

землях, втрати $з$ систем водопостачання, відсутність або недостатня робота систем водовідведення поверхневого стоку, недостатня робота вертикального дренажу $[1,3,5,8,9,10,12]$.

Заумови розвитку тавідновлення зрошення в таких умовах необхідно забезпечити функціонування існуючих систем захисту від підтоплення, підтримання їх у робочому стані, модернізацію та удосконалення [11].

Для вирішення проблеми підтоплення в регіоні розроблено удосконалену конструкцію дренажної системи, яка включає мережу відкритих і закритих колекторів для акумуляції поверхневого стоку і пониження РГВ до позначок нижче критичних. Система передбачає підключення до свердловини вертикального дренажу та відведення надлишкових вод 3 населеного пункту та прилеглої території в Північно-Кримський канал за допомогою напірного трубопроводу [8]. Запропоноване рішення закладено в робочий проект «Захист від шкідливої дії вод смт Нова Маячка Цюрупинського району».

Висновки. Належність зони зрошення ПКК до старовинної тераси дельти Дніпра 3 безстічними формами рельєфу, інтенсивне зрошення та розвантаження зони грунтового потоку на фоні вертикального дренажу зумовили високий ризик затоплення і підтоплення територій. Питома кількість ризиків утворення стійкого підтоплення на території становить 2-3 рази на 10 років.

Розроблено конструкцію дренажної системи зі спільною дією горизонтального та вертикального дренажу, яка включає водовідвідні канави, відкриті колектори, штучні водойми та водозахисні вали для прийому і акумуляції поверхневого стоку, та мережу горизонтального і вертикального дренажу для регулювання грунтових вод.

\section{Бібліографія}

1. Абрамов И. Б., Звягинцева Н.А., Черненко С.А. Формирование гидрогеологомелиоративной обстановки в зоне Северо-Крымского канала и территории Херсонской области // Сб. науч. тр. УкрНИИГиМ. Київ: Урожай, 1983. С. 34-42

2. Бабіцька О. А. Ефективність систем інженерного захисту від підтоплення самопливного та примусового типу та напрями їх удосконалення: автореф. дис. на здобуття наук. ступеня канд. техн. наук: спец. 06.01.02 «Сільськогосподарські меліорації». Київ, 2010.21 с.

3. Грановська Л.М., Жужа П.В. Теоретичне обгрунтування інженерних заходів з боротьби зі шкідливою дією вод на території смт Нова Маячка Цюрупинського району Херсонської області // Зрошуване землеробство. Міжвідомчий тематичний науковий збірник. Херсон: Грінь Д.С., 2015. Вип. 64. С. 79-82.

4. Дренажные системы в зоне орошения / Н.Г. Бугай, и др.; Под ред. А.Я. Олейника. Київ: Урожай, 1986. 192 с

5. Інженерний захист територій: Навч. посібник / А.М. Рокочинський та ін; за ред. А.М. Рокочинського, Херсон: ОЛДІ ПЛЮС, 2017. 414 с.

6. Клімат України / За ред. В.М. Ліпінського, В.А. Дячука, В.М. Бабіченко, Київ: Видавництво Раєвського, 2003. 343 с.

7. Молодых И. И. Грунты подов и степных блюдец субаэрального покрова Украины (гидрогеологические и инженерно-геологические особенности). Киев: Наук. думка, 1982. 160 с.

8. Дренажна система: пат. 128616 Україна № u 201804055; заявл. 13.04.2018; опубл. 25.09.2018, Бюл № 18.

9. Ромащенко М.І., Драчинська Е.С., Шевченко А.М. Інформаційне забезпечення зрошуваного землеробства. Концепція, структура, методологія організації; ред. М.I. Ромащенка, Київ: Аграрна наука, 2005. $196 \mathrm{c}$. 
10.Ромащенко М., Шевченко А., Савчук Д., Крученюк В. Стан та проблеми вертикального дренажу в Херсонській області // Водне господарство України. 2007. № 4. С. 44-55.

11.Наукові засади розвитку аграрного сектора економіки південного регіону України / За наук. ред. М.І. Ромащенка, Р.А. Вожегової, А.П. Шатковського, Херсон: ОЛДІ-ПЛЮС, 2017. 438 c.

12.Харламов О.І. Роль вертикального дренажу в забезпеченні захисту від підтоплення в зоні зрошення Північно-Кримського каналу // Всесвітній день води: Всеукраїнська наук.-практ. конф.: тези доп., Київ: ІВПіМ НААН, 2016. С. 132-133.

\section{References}

1. Abramov, I. B., Zviahyntseva. N.A.. \& Chernenko. S.A. (1983). Formyrovanye hydroheolohomelyoratyvnoi obstanovky $\mathrm{v}$ zone Severo-Krymskoho kanala y terrytoryy Khersonskoi oblasty [Formation of a hydrogeological-meliorative situation in the zone of the North-Crimean Canal and the territory of the Kherson region] Sb. nauch. tr. UkrNYYHyM. Kyiv: Urozhai. 34-42. [in Russian|.

2. Babitska. O.A. (2011). Efektivnist' sistem inzhinernogo zahistu vid pidtoplenia samoplyvnogo typu ta prymusovogo typu ta napriamy iih udoskonalenia. [Efficiency of systems of engineering protection against flooding of self-propelled and forced type and directions of their improvement]. Extended abstract of candidate s thesis. Kyiv. [in Ukrainian].

3. Granovska. L., \& Zhuzha. P. (2015). Teoretychne obhruntuvannia inzhenernykh zakhodiv $z$ borot'by zi shkidlyvoiu diieiu vod na terytorii smt Nova Maiachka Tsiurupyns koho raionu Khersons koi oblasti [Theoretical substantiation of the engineering measures to control harmful water effect on the territory of the urban-type settlement of Nova Maiachka, Tsiurupynsk Raion. Kherson oblast|. Tavriys k kyy naukovyy visnyk. Kherson: Grin` D.S., 64, 79-82. [in Ukrainian].

4. Bygai, N.G., Vinogradov, S.G., \& Vnychkov, V.V. et al. (1987). Drenazhnue sistemu v zone orosheniia. [Drainage systems in the irrigation zone]. Kyiv: Urozhay. [in Russian|.

5. Rokochynskyi. A.M., Zhyvytsia, V.A., Volkova, L.A., \& Romashchenko, M.I. (2017). Inzhenernyi zakhyst terytorii [Engineering protection of territories|. Kherson: OLDI Plus. [in Ukrainian]

6. Lipinskyi, V.M., Diachuk, V.A., \& Babichenko, V.M. (2003). Klimat Ukrainy [The climate of Ukraine]. Kyiv: Vydavnytstvo Raievskoho. [in Ukrainian].

7. Molodyh, I. I. (1982). Grunty podov y stepnykh bliudets subaeralnoho pokrova Ukrayny (gydroheolohycheskye y inzhenerno-geolohycheskye osobennosty) [Soil pods and steppe saucers of the subaerial cover of Ukraine (hydrogeological and engineering-geological features)|. Naykova dymka. [in Russian].

8. Savchuk, D.P., Babitska, O.A., Kotykovych, I.V., \& Kharlamov, O.I. (2018). Drenazhna systema [Drainage system]. Patent of Ukraine. №128616. [in Ukrainian].

9. Romashchenko M.I., Drachinskaia E.S., \& Shevchenko A.M. (2005). Informaciyne zabezpechennia zroshyvanogo zemlerobstva. Konceptsiia, stryktyra, metodologiia organizatsiii. [Information provision for irrigated agriculture. Concept, structure, methodology of organization]. Kyiv: Agrarna nayka. [in Ukrainian].

10.Romashchenko, M., Shevchenko, A., Savchuk, D., \& Krucheniuk, V. (2007). Stan ta problemy vertykalnoho drenazhu v Khersonskii oblasti [Status and problems of vertical drainage in the Kherson region]. Vodne gospodarstvo Ukrainy, 4, 44-55. [in Ukrainian].

11. Romashchenko,M.I., Vozhehova,R.A.,\&Shatkovskyi,A.P.(Ed.)(2017).Naukovizasady rozvytku ahrarnoho sektora ekonomiky pirdennoho rehionu Ukrainy [Scientific principles of development of the agrarian sector of the economy of the southern region of Ukraine]. Kherson: OLDI-Plus, 438. [in Ukrainian].

12.Kharlamov, O.I. (2016). Rol'vertykalnoho drenazhu v zabezpechenni zakhystu vid pidtoplennia v zoni zroshennia Pivnichno-Krymskoho kanalu [The role of vertical drainage in providing protection against flooding in the irrigation zone of the North-Crimean Canal]. Vseukrainska nauk.-prakt. konf.: tezy dop., Kyiv: IVPiM NAAN, 132-133. [in Ukrainian]. 


\section{Риски подтопления и пути их уменьшения в зоне орошения Северо-Крымского канала}

А.И. Харламов

Аннотация. Установлена интенсивность рисков подтопления и закономерности режима РГВ в многолетнем разрезе в зоне Северо-Крымского канала в бессточных условиях на фоне вертикального дренажа. Разработана конструкиия дренажной системы с обиим действием горизонтального и вертикального дренажа.

Ключевые слова: орочение, подтопление, дренаж, уровень грунтовых вод, бессточный рельеф местности

Risks of flooding and the ways of their reduction

O.I. Kharlamov

in the irrigation zone of the North-Crimean Canal

Abstract. The intensity of chance of flooding and regularity of the ground water level mode in a longterm section in a zone of the North Crimean Canal in drainless conditions against the background of a vertical drainage is established. The design of drainage system with the common action of a horizontal and vertical drainage is developed.

Key words: irrigation, flooding, drainage, groundwater levels, terrain relief without runoff. 